\title{
Antibacterial evaluation silver of nanocomposite on Staphylococcus aureus and Escherichia coli
}

\author{
Klebson Silva Santos ${ }^{1 *}$, Ana Paula Barreto Prata Silva', Andriele Mendonça Barbosa², Isabelle Souza de Mélo Silva²,

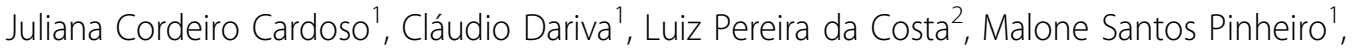 \\ Francine Ferreira Padilha'
}

From 5th Congress of the Brazilian Biotechnology Society (SBBIOTEC)

Florianópolis, Brazil. 10-14 November 2013

\section{Background}

The treatment of bacterial diseases has become an increase public health problem, since the conventional antimicrobial substances lose their effectiveness due to the microbial resistance phenomenon [1]. Silver is a metal with potential antibacterial activity, and showed significant efficacy against several species of bacteria. The silver activity to prevent microbial growth is enhanced when the metal is found as nanoparticles [2]. Silver nanoparticles (NPAG) have their bacteriostatic and bactericidal activity based on their ability to kill or inhibit growth of bacteria. Pathogenic microorganisms, both gram positive and negative were sensitive to NPAG. The NPAG may be employed in conjunction with the biopolymers forming a nanocomposite that emerge as a promising therapeutic alternative. The xanthan gum is a biopolymer with interesting properties for food, cosmetic and pharmaceutical industries, acting as gelling and stabilizing [3]. The present study in focused on the evaluation of silver nanocomposite activity against gram positive and gram negative bacteria. The disk diffusion well technique was used to assess the efficiency of the silver nanocomposites against Staphylococcus aureus and Escherichia coli. The results indicated that the developed product has a broad spectrum of activity against the tested bacteria.

\section{Methods}

The silver nanocomposite NAG was synthesized by Xanthomonas 629, using silver nitrate in the fermentation media. The size of the nanoparticles was obtained by transmission electron microscopy. The metal concentration in the polymer was determined by atomic absorption spectrometric. The bacteria used in this study were Staphylococcus aureus and Escherichia coli. The evaluation of antimicrobial activity was assessed by the method of holes in wells, based on Mueller-Hinton agar. The abovementioned microorganisms were scattering from a microbial solution $10^{8}$, and the holes were subsequently filled with $50 \mu \mathrm{L}$ of a silver nanoparticles (test ) solution and $50 \mu \mathrm{L}$ of a xanthan gum alone (control) solution. All experiments were conducted in triplicate. An adaptation of the Kirby \& Bauer technique using microbial suspension of $10^{8}$ bacteria was also used for observing possible inhibition zones after incubation in bacteriological incubator at $37^{\circ} \mathrm{C}$ for 24 hours.

\section{Results and conclusion}

The analysis of transmission electron microscopy showed NAG about $3 \pm 2 \mathrm{~nm}$ in size medium. The atomic absorption spectrometry showed a concentration of $49,2 \mathrm{mg} / \mathrm{g}$ of metal per gram of NAG. The antimicrobial activity of silver NAG showed inhibition zones of $12.2 \pm 0,3 \mathrm{~mm}$ and $11.6 \pm 0,5 \mathrm{~mm}$ for Escherichia coli and Staphylococcus aureus, respectively. Both microorganisms were evaluated at a concentration of $5 \mathrm{mg}$ NAG. The disk diffusion assay indicated that the sensitive zone of inhibition was $9.6 \pm 0,4 \mathrm{~mm}$ and $9.7 \pm$ $0,3 \mathrm{~mm}$ respectively for these pathogens, the control xanthan gum was not able of inhibit the growth of any pathogens tested. the results, it was concluded that the nanocomposite studied in this work presented a broad spectrum of antimicrobial activity, suggesting that use can be a viable alternative for the treatment of pathogenic organisms.

'Universidade Tiradentes, RENORBIO, Aracaju, 49032-490, Brazil

Full list of author information is available at the end of the article 


\section{Acknowledgements}

Authors would like to express their gratitude to CNPq, CAPES and FAPITEC

for the financial support and scholarships.

\section{Authors' details}

'Universidade Tiradentes, RENORBIO, Aracaju, 49032-490, Brazil. ${ }^{2}$ Universidade

Tiradentes, Campus Farolândia, Aracaju, 49032-490, Brazil.

Published: 1 October 2014

\section{References}

1. Oveise H, Simin R, Xiangfen J, Yoshiaki A, Ali B, Soichi W, Yusuke Y: Improved Inactivation Effect of Bacteria: Fabrication of Mesoporus Anatase Films With Fine Ag Nanopartícles Prepared by Coaxial Vacuum Are Deposition Chemistry. Letters 2011, 420:422

2. Theivasanthi TE, Alagar M: Anti-bacterial Studies of Silver Nanoparticles. Mendeley 2011, 1101:5.

3. Ghazal SMA, Elsayed WS, Badr UM, Gebreel HM, Khalil KMA: Genetically Modified Strains of Xanthomonas campestris Higher Xanthan Producer and Capable to Utilize Whey. Current Research in Bacteriology 2011, 44:62.

doi:10.1186/1753-6561-8-S4-P8

Cite this article as: Santos et al: Antibacterial evaluation silver of nanocomposite on Staphylococcus aureus and Escherichia coli. BMC Proceedings 2014 8(Suppl 4):P8.

\section{Submit your next manuscript to BioMed Central} and take full advantage of:

- Convenient online submission

- Thorough peer review

- No space constraints or color figure charges

- Immediate publication on acceptance

- Inclusion in PubMed, CAS, Scopus and Google Scholar

- Research which is freely available for redistribution

Submit your manuscript at www.biomedcentral.com/submit 